\title{
PENGELOLAAN LIMBAH INDUSTRI TAHU MENGGUNAKAN BERBAGAI JENIS TANAMAN DENGAN METODE FITOREMEDIASI
}

\author{
${ }^{1}$ Bambang Sigit Aris, ${ }^{2}$ Rudi, dan ${ }^{3}$ Lasarido \\ ${ }^{1}$ Program Studi Agroteknologi, ${ }^{2 \& 3}$ Dosen Program Studi Agroeknologi Sekolah Tinggi \\ Pertanian Kutai Timur, Kalimantan Timur, Jl. Soekarno Hatta, Sangatta Utara. \\ Email: azwasativa@gmail.com; azwasativa@gmail.com
}

\begin{abstract}
ABSTRAK
Pengelolaan Limbah Industri Tahu Menggunakan Berbagai Jenis Tanaman Dengan Metode Fitoremediasi.

Limbah produksi tahu mengandung kadar protein yang tinggi dan dapat segera terurai. Limbah cair ini sering dibuang secara langsung tanpa pengolahan terlebih dahulu sehingga menghasilkan bau busuk dan mencemari sungai. Penelitian ini merupakan penelitian deskriptif dengan tujuan untuk mengetahui apakah penggunaan berbagai jenis tanaman yang terdiri dari: fermentasi, kangkung, bayam merah, dan selada mampu menyerap polutan limbah cair tahu dengan metode fitoremediasi dan berapa persentasenya. Hasil dari penelitian ini adalah pemanfaatan berbagai jenis tumbuhan mampu menyerap dan memberikan persentase penurunan pencemar limbah cair tahu pada masing-masing parameter. Untuk nilai TSS tertinggi terdapat pada tanaman bayam merah sebesar 72,67\%, untuk parameter penurunan BOD tertinggi terdapat pada tanaman bayam merah sebesar $66,28 \%$, untuk parameter COD tertinggi terdapat pada tanaman kangkung sebesar $46,43 \%$, untuk peningkatan $\mathrm{pH}$ tertinggi pada fermentasi 3,75 dan penurunan suhu tertinggi pada fermentasi sebesar $48,275 \%$.
\end{abstract}

Kata kunci : Berbagai jenis tanaman dan Limbah cair tahu.

\begin{abstract}
Tofu Industrial Waste Management Using Various Types Of Plants With Phytoremediation Methods.

Tofu production waste contains hight levels of protein and can be decomposed immediately. This liquid waste is often disposed of directly without prior treatment, resulting in a foul odor and polluting the river. This research is a descriptive study with the aim to find out whether the use of various types of plants consisting of: fermentation, kale, red spinach, and lettuce are able to absorb the pollutants in tofu liquid waste by the phytoremediation method and how much percentage of absorption.The results of this study are the use of various types of plants capable of absorbing and giving a percentage decrease in pollutants in tofu liquid waste in each parameter. For the highest value in TSS found in red spinach plants by $72.67 \%$, for the highest decrease BOD parameters found in red spinach plants by $66.28 \%$, for the highest COD parameters found in kale plants by $46.43 \%$, for an increase in $\mathrm{pH}$ the highest is in the fermentation at 3.75 and the highest temperature reduction is in the fermentation at $48.275 \%$..
\end{abstract}

Key words : Tofu liquid waste and various types of plants.

\section{PENDAHULUAN}

Limbah cair adalah limbah dalam bentuk cair yang dihasilkan oleh kegiatan industri yang dibuang ke lingkungan dan diduga dapat menurunkan kualitas lingkungan (Keputusan Menteri Negara Lingkungan Hidup nomar 51 tahun 1995). Dampak yang ditimbulkan oleh pencemaran limbah industri tahu adalah gangguan terhadap kehidupan biotik dan turunnya kualitas air akibat meningkatnya kandungan bahan organik dalam air.

Pada proses pembuatan tahu, limbah cair dihasilkan dari proses pencucian, perendaman, hasil 
penggumpalan, pengepresan, dan tumpahan serta pembersihan tempat. Karakteristik buangan industri tahu meliputi dua hal, yaitu karakteristik fisika dan kimia. Karakteristik fisika meliputi padatan total, padatan tersuspensi, suhu, warna, dan bau. Karakteristik kimia meliputi bahan organik, bahan anorganik dan gas. Suhu air limbah tahu berkisar $37-45^{\circ} \mathrm{C}$, kekeruhan 535-585 FTU, warna 2.2252.250 Pt.Co, amonia 23,3-23,5 mg/1, BOD 6.000-8.000 mg/1 dan COD 7.500-14.000 mg/1 (Herlambang, 2002).

Limbah industri tahu dapat memberikan dampak yang tidak baik terhadap kualitas air, yang disebabkan oleh meningkatnya kandungan bahan organik dalam air. Dan juga menganggu kehidupan biotik (Herlambang, 2002; Nurhasan dan Pramudyanto, 1991).

Adapun tujuan dari penelitian ini adalah untuk mengetahui apakah penggunaan berbagai jenis tanaman mampu menurunkan kadar bahan cemar dalam limbah cair tahu dan seberapa banyak presentase penurunan dari penggunaan berbagai jenis tanaman terhadap kadar bahan cemar dalam limbah cair tahu.

\section{METODA PENELITIAN}

\subsection{Tempat dan Waktu}

Penelitian ini dilaksanakan di Gang Seroni, Sangatta Utara. Penelitian dilaksankan selama kurang lebih 2 bulan terhitung dari bulan Mei 2020 sampai bulan Juni 2020.

\subsection{Bahan dan Alat}

Alat dan bahan yaitu wadah untuk menyimpan limbah cair tahu, sterofoam, netpot, rockwool, cutter, ember, jergen, penggaris, pulpen, pensil, kawat, palu, paku, balok, dan kamera. Bahan yang digunakan dalam penelitian ini yaitu air PDAM , limbah cair tahu, tanaman bayam, tanaman kangkung dan tanaman selada, plastik UV serta paranet.

\subsection{Metode Penelitian}

Penelitian ini adalah penelitian deskriptif, yang bermaksud untuk mengeksplorasi dan klarifikasi suatu fenomena atau fakta sosial, dengan jalan menjabarkan beberapa variabel yang berkaitan dengan masalah yang diteliti (Iqbal, 2004).

Dalam penelitian ini parameter yang diamati adalah sebagai berikut : Total Suspended Solids (TSS), Biologycal Oxygen Demand (BOD), Chemical Oxygen Demand (COD), $\mathrm{pH}$ dan Temperatur.

Dalam penelitian ini menggunakan 2 rumus yaitu :

Presentase Penurunan Parameter Kualitas (Darajeh et al., 2014), dengan rumus sebagai berikut :

Keterangan,

$$
\% \text { Perubahan }=\frac{a-b}{a} \times 100 .
$$

a adalah nilai awal limbah tahu dan

$\mathrm{b}$ adalah nilai akhir limbah tahu.

Terkhusus untuk $\mathrm{pH}$, menggunakan $\mathrm{b}$ - a (nilai akhir yang di kurang dengan nilai awal) untuk membandingkan selisih sebelum dan sesudah penggunaan limbah tahu.

Regresi nonparametric (Eubank, 1988), dengan rumus sebagai berikut :

$$
y_{i}: f\left(x_{i}\right)+\varepsilon_{i}, \quad i=1,2 \ldots . . n \text {. }
$$

dimana $y_{i}$ adalah variabel respon, 
$x_{i}$ adalah variabel prediktor,

$f$ merupakan fungsi regresi yang polanya tidak diketahui

serta $\varepsilon_{i}$ merupakan variabel acak dengan nilai tengah nol dan ragam $\mathrm{N}\left(0, \mathrm{o}^{2}\right)$, dan

kurva $f$ hanya di asumsikan mulus (smooth) serta berada dalam suatu ruang fungsi tertentu. Untuk uji regresi menggunakan EXCEL 2013 karena lebih mudah dan efisien.

\section{HASIL PENELITIAN DAN PEMBAHASAN}

Limbah cair tahu diambil pada pabrik rumahan Tahu Dan Tempe Seroni, Gang Seroni, Sangatta Utara yang dimiliki oleh bapak Suwondo dan dijadikan sebagai sampel. Sampel tersebut, kemudian dibawa ke Laboratorium Kualitas Air Fakultas
Perikanan Dan Ilmu Kelautan Universitas Mulawarman, Samarinda, untuk di analisis dan untuk mengetahui kadar bahan cemar seperti Total Suspended Solid, Biologycal Oxygen Demand, Chemical Oxygen Demand, Potensial Hydrogen dan Temperatur Suhu dalam limbah cair tahu dengan hasil seperti pada tabel 1 di bawah ini :

Tabel 1. Hasil analisis limbah tahu sebelum diberikan perlakuan

\begin{tabular}{|c|c|c|c|}
\hline No & Bahan Cemar & Baku Mutu & Hasil analisa \\
\hline 1 & (TSS) & $100 \mathrm{mg} / \mathrm{l}$ & $322 \mathrm{mg} / \mathrm{l}$ \\
\hline 2 & BOD) & $150 \mathrm{mg} / \mathrm{l}$ & $105 \mathrm{mg} / \mathrm{l}$ \\
\hline 3 & $(\mathrm{COD})$ & $300 \mathrm{mg} / \mathrm{l}$ & $98,261 \mathrm{mg} / \mathrm{l}$ \\
\hline 4 & $(\mathrm{pH})$ & $6-9$ & 3,29 \\
\hline 5 & suhu & $38^{\circ} \mathrm{C}$ & $49,3^{\circ} \mathrm{C}$ \\
\hline
\end{tabular}

Sumber :1. Peraturan Daerah Provinsi Kalimantan Timur No. 2 Tahun 2011 Tentang Pengelolaan Kualitas Air Dan Pengendalian Pencemaran Air. 2. Laboratorium Kualitas Air Fakultas Perikanan Dan Ilmu Kelautan Universitas Mulawarman, Samarinda.

Pada tabel 1 di atas, untuk parameter TSS, $\mathrm{pH}$ dan Temperatur melebihi baku mutu air limbah industri tahu dengan nilai TSS sebesar $322 \mathrm{mg} / \mathrm{l}$, $\mathrm{pH}$ sebesar 3,29 dan temperatur sebesar $49,3{ }^{\circ} \mathrm{C}$. Akan tetapi untuk nilai BOD dan COD sudah berada di bawah standar baku mutu air limbah industri tahu yaitu nilai BOD sebesar $105 \mathrm{mg} / \mathrm{l}$ dan COD sebesar $98,261 \mathrm{mg} / \mathrm{l}$. Kondisi yang demikian berpotensi menimbulkan pencemaran jika tidak dilakukan pengendalian sebelum di salurkan keluar, baik pada tanah maupun perairan, terutama pada parameter TSS, pH dan Temperatur.

\subsection{Total Suspended Solids (TSS)}

Hasil uji perubahan persentase penurunan total suspended solid (TSS) pada limbah cair tahu dengan menggunakan sistem fitoremediasi pada jenis tanaman: kangkung, bayam merah, selada dan fermentasi dapat memberikan hasil yang berbeda dalam menurunkan kadar TSS pada limbah cair tahu dengan hasil seperti pada tabel 2 di bawah ini : 
Tabel 2. Total suspended solid

\begin{tabular}{|c|c|c|c|c|c|}
\hline \multirow[t]{2}{*}{ No } & \multirow[t]{2}{*}{ Bahan cemar } & \multicolumn{4}{|c|}{ Perlakuan fitoremediasi } \\
\hline & & fermentasi & kangkung & Bayam merah & selada \\
\hline 1 & TSS & $55,59 \%$ & $67,08 \%$ & $72,67 \%$ & $32,30 \%$ \\
\hline \multicolumn{6}{|c|}{ Persentase penurunan } \\
\hline
\end{tabular}

Pada tabel 2 di atas, memperlihatkan hasil yang didapatkan setelah menggunakan rumus persen perubahan yang memberikan persentase penurunan terhadap total suspended solid (TSS) dalam limbah cair tahu dengan sistem fitoremediasi. Semua perlakuan memberikan persentase penurunan, yakni fermentasi memberikan penurunan sebesar 55,59\%, tanaman kangkung sebesar $67,08 \%$, tanaman bayam merah sebesar $72,67 \%$ dan tanaman selada sebesar 32,298\%. Dapat kita lihat bahwasanya persentase penurunan TSS tertinggi terdapat pada tanaman bayam merah yaitu dengan nilai persentase sebesar 72,67\%, sedangkan untuk persentase penurunan TSS yang terrendah terdapat pada tanaman selada yaitu sebesar 32,298 \%. Eksperimen yang melibatkan akumulasi biologis kontaminan logam dirangkum dalam artikel. Fokusnya adalah pada identifikasi spesies tanaman hiperakumulasi untuk kadmium dan seng. Dua dari studi meneliti Thlaspi caerulescens (alpine pennycress) sebagai bioadsorben (Chaney et al., 1996). Hasil penelitian ini menunjukkan bahwa selama 28 hari Eichhornia crassipes yang ditumbuhkan pada $25 \%$ limbah cair tapioka mampu menurunkan konsentrasi BOD, COD, dan $\mathrm{CN}$ limbah cair serta meningkatkan $\mathrm{pH}$ campuran air cair dan air murni (Felani dan Hamzah, 2007). Hasil penelitian fitoremediasi dengan 5 batang kangkung pada 5 liter air didapatkan penurunan kadar $\mathrm{Pb} 0,001 \mathrm{mg} / \mathrm{L}$, untuk 10 batang 0,077 $\mathrm{mg} / \mathrm{L}$ dan penambahan 15 batang kangkung sebesar 0,112 mg/l. Hasil penelitian ini menunjukkan perbedaan yang signifikan dengan nilai Asymp. Sig $0,000<0,05$. Tanaman Ipomoea aquatica mampu menurunkan kadar timbal $(\mathrm{Pb})$ dalam air limbah namun penurunannya masih belum bisa di bawah ambang batas yang ditetapkan dalam standar Peraturan Gubernur Jawa Timur Nomor 72 Tahun 2013 sebesar 0,1 mg/L (Juwita et al., 2018). Pengolahan limbah kadmium dapat dilakukan dengan metode adsorpsi menggunakan tanaman bayam duri (Amaranthus spinosus L). Tumbuhan ini digunakan sebagai adsorben karena mengandung protein yang memiliki gugus amina (-NH2), karboksil ($\mathrm{COOH})$, serta gugus sulfhidril $(-\mathrm{SH})$. Selain itu, pada jaringan tumbuhan terdapat dinding sel yang tersusun dari selulosa, lignin yang mengandung gugus hidroksil (-OH). Gugus polar ini mampu mengikat logam berat. Tujuan dari penelitian ini adalah untuk mengetahui daya serap tanaman bayam terhadap paku logam kadmium $(\mathrm{Cd})$ pada jaringan akar, batang dan daun dengan variasi waktu kontak (Mohamad, 2013).

\subsection{Biologycal Oxygen Demand (BOD)}

Hasil uji perubahan persentase penurunan Biologycal Oxygen Demond (BOD) dalam limbah cair tahu dengan menggunakan sistem fitoremediasi pada 
jenis tanaman : kangkung, bayam merah, selada dan fermentasi memberikan hasil yang berbeda dalam menurunkan bahan cemar dalam limbah tahu dengan hasil seperti pada tabel 3 di bawah ini

Tabel 3. Biologycal Oxygen Demand

\begin{tabular}{|c|c|c|c|c|c|}
\hline \multirow{2}{*}{ No } & \multirow{2}{*}{ Bahan cemar } & \multicolumn{4}{|c|}{ Perlakuan fitoremediasi } \\
\hline & & fermentasi & kangkung & Bayam merah & selada \\
\hline 1 & BOD & $41,523 \%$ & $56,285 \%$ & $66,28 \%$ & $50,666 \%$ \\
\hline \multicolumn{6}{|c|}{ sentase penurunan } \\
\hline
\end{tabular}

Pada tabel 3 di atas, BOD memberikan persentase penurunan pada setiap perlakuan. Untuk perlakuan dengan fermentasi diperoleh nilai penurunan sebesar $41,523 \%$, tanaman kangkung diperoleh penurunan sebesar $56,285 \%$, tanaman bayam merah di peroleh penurunan sebesar $66,28 \%$ dan pada tanaman selada diperoleh penurunan sebesar 50,666\%. Bisa kita lihat bahwa penurunan yang paling tinggi terdapat pada tanaman bayam merah yaitu berkisar 66,28\%, sedangkan untuk persentase penurunan yang terendah terdapat pada perlakuan fermentasi yaitu berkisar $41,523 \%$.

Tanaman bayam merah memberikan hasil tertinggi terhadap penyerapan BOD dikarenakan tanaman bayam memiliki akar yanag bentuknya meruncing sehingga mudah menembus tanah atau air. Fungsi akar sebagai tempat masuknya mineral (zat-zat hara) dari tanah atau air menuju ke seluruh bagian tumbuhan, juga untuk menunjang dan meperkokoh berdirinya tumbuhan ditempat hidupnya (Sunarjono, 2003; Bandini et al., 2004; Ashari, 2009; Alpian, 2013; Anggara, 2009; Dalimartha, 2006; Haryanto et al., 1996; Heddy, 1990; Nazaruddin, 1999).

\subsection{Chemical Oxygen Demand (COD)}

Hasil uji perubahan persentase penurunan Chemical Oxygen Demand (COD) pada limbah cair tahu dengan menggunakan sistem fitoremediasi pada jenis tanaman : kangkung, bayam merah, selada dan fermentasi memberikan hasil yang berbeda dalam menurunkan bahan cemar dalam limbah cair tahu dengan hasil seperti pada tabel 4 di bawah ini :

Tabel 4. Chemical Oxygen Demand

\begin{tabular}{lcccc}
\hline \multirow{2}{*}{ No } & Bahan cemar & \multicolumn{4}{c}{ Perlakuan fitoremediasi } \\
\cline { 3 - 5 } & fermentasi & kangkung & Bayam merah & selada \\
\hline $\begin{array}{l}\text { COD } \\
\text { Persentase penurunan }\end{array}$ & $43,666 \%$ & $46,43 \%$ & $44,771 \%$ & $39,244 \%$ \\
\hline
\end{tabular}

Pada tabel 4 di atas menunjukan bahwa COD mengalami penurunan pada setiap perlakuan. Untuk perlakuan fermentasi, memberikan persentase penurunan sebesar $43,666 \%$, tanaman kangkung mengalami penurunan sebesar $46,43 \%$, tanaman bayam merah memberikan persentase penurunan 
sebesar 44,771\%, dan pada tamanan selada mengalami penurunan sebesar $39,244 \%$. Dapat kita lihat bahwa yang memberikan persentase penurunan tertinggi terdapat pada tanaman kangkung yaitu sebesar $46,43 \%$, sedangkan untuk persentase penurunan yang terrendah terdapat pada tanaman selada yaitu sebesar 39,244\%.

Tanaman kangkung memiliki nilai penurunan COD yang tertinggi, hal ini tidak lain karena tanaman kangkung merupakan tanaman yang mempunyai daya adaptasi yang cukup luas terhadap kondisi iklim dan tanah di daerah tropis, sehingga dapat ditanam di berbagai daerah diIndonesia. Kangkung juga merupakan tanaman yang tidak selektif terhadap unsur hara tertentu, sehingga dapat menyerap semua unsur yang terkandung di dalam tanah maupun air. Kangkung dapat tumbuh dengan baik pada badan air yang tidak terlalu dalam atau bantaran sungai, danau, dan selokan (Hapsari et al., 2018).

\subsection{Potensial Hydrogen (pH)}

Hasil uji perubahan persentase peningkatan terhadap Potensial Hydrogen (pH) pada limbah cair tahu dengan menggunakan sistem fitoremediasi pada jenis tanaman : kangkung, bayam merah, selada dan fermentasi memberikan hasil yang berbeda dalam menurunkan bahan cemar dalam limbah cair tahu dengan hasil seperti pada tabel 5 di bawah ini :

Tabel 5. Potensial Hydrogen

\begin{tabular}{cccccc}
\hline \multirow{2}{*}{ No } & Bahan cemar & \multicolumn{4}{l}{ Perlakuan fitoremediasi } \\
\cline { 3 - 5 } & fermentasi & kangkung & Bayam merah & selada \\
\hline $\begin{array}{c}\text { Persentase penurunan } \\
\text { Penyyyy}\end{array}$ & $113,98 \%$ & $83,89 \%$ & $92,09 \%$ & $90,88 \%$ \\
\hline
\end{tabular}

Pada tabel 5 di atas, di dapatkan hasil selisih kenaikan ph pada perlakuan fermentasi sebesar 113,98 \%, tanaman kangkung sebesar 83,89 \%, tanaman bayam merah sebesar $92,09 \%$ dan untuk tanaman selada sebesar 90,88\%. Untuk $\mathrm{pH}$ air yang memberikan persentase kenaikan tertinggi terdapat pada perlakuan fermentasi yaitu berkisar $113,98 \%$ hal ini memberikan hasil yang semula asam dapat berubah menjadi netral, sedangkan untuk kenaikan yang terrendah terdapat pada tanaman kangkung yaitu berkisar 83,89\% yang membuatnya tetap menjadi asam.

\subsection{Temperatur (suhu)}

Hasil uji perubahan persentase penurunan terhadap Temperatur pada limbah cair tahu dengan menggunakan sistem fitoremediasi pada jenis tanaman : kangkung, bayam merah, selada dan fermentasi memberikan hasil yang berbeda dalam menurunkan temperatur dalam limbah cair tahu dengan hasil seperti pada tabel 6 di bawah ini :

Tabel 6. Temperatur

\begin{tabular}{ccccc}
\hline \multirow{2}{*}{ No } & Bahan cemar & \multicolumn{4}{c}{ Perlakuan fitoremediasi } \\
\cline { 2 - 5 } & fermentasi & kangkung & Bayam merah & selada \\
\hline $\begin{array}{c}1 \\
\text { Persentase penurunan }\end{array}$ & $48,275 \%$ & $47,058 \%$ & $46,653 \%$ & $47,261 \%$ \\
\hline
\end{tabular}


Pada tabel 6 di atas, menunjukan bahwa dengan menggunakan tanaman : kangkung, bayam merah, selada dan fermentasi ini memberikan hasil yang tidak jauh berbeda antara perlakuan yang satu dengan perlakuan yang lain. Hal ini karena nilai persentase antar perlakuan tidak jauh berbeda. Seperti perlakuan fermentasi memberikan nilai sebesar $48,275 \%$, tanaman kangkung sebesar $47,058 \%$, tanaman bayam merah sebesar $46,653 \%$ dan pada tanaman selada sebesar 47,261.

Untuk nilai tertinggi terdapat pada perlakuan fermentasi yakni sebesar $48,275 \%$, hal ini dikarenakan pada perlakuan ini tidak terdapat penutup seperti perlakuan lain yang memiliki penutup sebagai tempat berdiri untuk tanaman. Perlakuan fermentasi berhubungan langsung dengan iklim sekitar seperti terkena sinar matahari langsung, tertiup angin dan walaupun beratapkan plastik uv, saat hujan cuaca dingin masih bisa masuk ke dalam air, seperti yang dikatakan oleh Effendi ( 2003) bahwasanya suhu pada badan air dapat dipengaruhi oleh musim, lintang, waktu dalam hari, sirkulasi udara, penutupan awan dan aliran serta kedalaman air.

\section{KESIMPULAN}

Dari hasil penelitian yang telah dilakukan, didapatkan kesimpulan sebagai berikut : Setiap perlakuan yang digunakan dalam penelitian ini mampu menurunkan kadar bahan cemar dalam limbah cair tahu sesuai dengan paraeter yang digunakan.

Penggunaan berbagai jenis tanaman mampu memberikan persentase penurunan pada setiap parameter. Untuk nilai tertinggi pada TSS terdapat pada tanaman bayam merah sebesar 72,67 \%, untuk parameter BOD, penurunan tertinggi terdapat pada tanaman bayam merah sebesar $66,28 \%$, untuk parameter COD, penurunan tertinggi terdapat pada tanaman kangkung sebesar 46,43\%, untuk peningkatan $\mathrm{pH}$ tertinggi terdapat pada perlakuan fermentasi sebesar 3,75 dan untuk penurunan temperatur tertinggi terdapat pada perlakuan fermentasi sebesar $48,275 \%$.

Hubungan antara BOD dan Suhu memiliki ikatan yang sangat kuat dibandingkan dengan hubungan dari perlakuan lainnya dengan nilai koefisien korelasi $(r)=0,956$, yang berada pada angka >0,76 - 0,99 (mendekati angka 1), dan nilai determinasi $\left(\mathrm{R}^{2}\right)=0,914$.

\section{DAFTAR PUSTAKA}

Alpian, Arham. (2013). Ciri-ciri tanaman kangkung. Http://100budidaya tanaman.blogspot.com/2013

09/ciri-ciri-tana mankangkung.html. Diakses pada tanggal 8 Februari 2020.

Anggara, R. (2009). Pengaruh kangkung darat (ipomea reptans poir.) Terhadap efek sedasi pada mencit balb/c. Fakultas kedokteran universitas diponegoro. Semarang.

Ashari, S. (1995). Hortikultura, Aspek Budidaya. Jakarta: Penerbit Universitas Indonesia.

Bandini, Yusni dan Nurudin, A. (2004). Bayam. Jakarta: Penebar Swadaya.

Chaney, R., Li, Y. M., \& Green, C. (1996). Potential use of metal hyperaccumulators (No. CONF960592-). International Business Communications, Southborough, MA (United States).

Dalimartha, S. (2006). Atlas Tumbuhan Obat Indonesia Jilid 4. Jakarta : Puspa Swara.

Darajeh, N., Idris, A., Truong, P., Abdul Aziz, A., Abu Bakar, R., \& Che 
Man, H. (2014). Phytoremediation potential of vetiver system technology for improving the quality of palm oil mill effluent. Advances in Materials Science and Engineering, 2014.

Effendi, H. (2003). Telaah Kualitas Air bagi Pengelolaan Sumberdaya dan Lingkungan Perairan. Cetakan Kelima. Yogjakarta: Kanisius.

Eubank, R.L, (1988). Nonparametric Regression and Spline Smoothing, second edition, Marcell dekker, Inc., New York.

Felani, M., \& Hamzah, A. (2007). Fitoremediasi limbah cair industri tapioka dengan tanaman enceng gondok. Buana Sains, 7(1), 11-20.

Juwita, E. H., Choirul, A., \& Adib, S. (2018).

EFEKTIVITAS

KANGKUNG AIR (Ipomoea aquatica) SEBAGAI FITOREMEDIASI

DALAM MENURUNKAN KADAR TIMBAL $(\mathrm{Pb})$ AIR LIMBAH BATIK. Analytical and Environmental Chemistry, 3(01), 30-37.

Hapsari, J.E. Amri, C. Suyanto, A. (2018). Efektivitas kangkung air (ipomoea aquatica) sebagai fitoremediasi dalam menurunkan kadar timbal (pb) air limbah batik. Politeknik Kesehatan Yogyakarta, Jl. Tatabumi No.3 , Banyuraden, Gamping, Sleman, Yogyakarta

Haryanto, W., Suhartini, T., \& Rahayu, D. (1996). Sawi dan selada. Jakarta: Penebar Swadaya.

Heddy, S. (1990). Biologi pertanian: tinjauan singkat tentang anatomi, fisiologi, sistematika, dan genetika dasar tumbuh-tumbuhan. Jakarta: Rajawali Press.

Herlambang, A. (2002). Teknologi Pengolahan Limbah Cair Industri Tahu. Samarinda: Pusat Pengkajian dan Penerapan Teknologi Lingkungan (BPPT) dan Badan Pengendalian Dampak Lingkungan. Jurnal Pengolahan Sampah, 4(2), 146-158.

Iqbal (2004). Penelitian Survey, dan Penelitian Deskriptif. Analisis Data Penelitian Dengan Statistik. Jakarta: bumi aksara.

Keputusan Menteri Negara Lingkungan Hidup Nomor : kep51/menlh/10/1995 tentang baku mutu limbah cair bagi kegiatan industri.

Laboratorium Kualitas Air Fakultas Perikanan Dan Ilmu Kelautan, (2020). Laporan hasil uji. Universitas Mulawarman, Samarinda.

Mohamad, E. (2013). Pengaruh variasi waktu kontak tanaman bayam duri terhadap adsorpsi logam berat kadmium (Cd). Jurnal entropi, $8(01)$

Nazaruddin, (1999). Budidaya dan pengaturan panen sayuran dataran rendah. Jakarta: Penebar swadaya.

Nurhasan dan Pramudyanto, B.B., (1991). Penanganan Air Limbah Tahu. Jakarta: yayasan Bina Karya.

Sunarjono, H. (2003). Bertanam 30 Jenis Sayur. Jakarta: Penebar Swadaya. 